\title{
Corrigendum: An extra-uterine system to physiologically support the extreme premature lamb
}

Emily A. Partridge, Marcus G. Davey, Matthew A. Hornick, Patrick E. McGovern, Ali Y. Mejaddam, Jesse D. Vrecenak, Carmen Mesas-Burgos, Aliza Olive, Robert C. Caskey, Theodore R. Weiland, Jiancheng Han, Alexander J. Schupper, James T. Connelly, Kevin C. Dysart, Jack Rychik, Holly L. Hedrick, William H. Peranteau \& Alan W. Flake

Nature Communications 8:15112 doi: 10.1038/ncomms15112 (2017); Published 25 Apr 2017; Updated 23 May 2017

A patent based on the work reported in this Article was inadvertently omitted from the Competing interests section of this article. The Competing interests statement should read:

E.M., A.F. and M.D. are co-authors on a patent entitled 'Extracorporeal life support system and methods of use thereof' (Patent no. WO2014145494 A1). The remaining authors declare no competing financial interests.

\footnotetext{
(c) Open Access This article is licensed under a Creative Commons Attribution 4.0 International License, which permits use, sharing, adaptation, distribution and reproduction in any medium or format, as long as you give appropriate credit to the original author(s) and the source, provide a link to the Creative Commons license, and indicate if changes were made. The images or other third party material in this article are included in the article's Creative Commons license, unless indicated otherwise in a credit line to the material. If material is not included in the article's Creative Commons license and your intended use is not permitted by statutory regulation or exceeds the permitted use, you will need to obtain permission directly from the copyright holder. To view a copy of this license, visit http://creativecommons.org/licenses/by/4.0/
}

(C) The Author(s) 2017 